\title{
AN ENERGY PROMISE OF DEMOCRATIC PEACE FOR THE ARCTIC: RUSSIA'S CASE
}

\begin{abstract}
It has been widely discussed whether the existing theoretical approaches within the international relations could efficiently explain the newly established phenomena within the international system. As a vast space of emerging importance, the Arctic presents a unique area which is an immanent strategic object of the world's major powers such as Russia, China, Canada, and the EU. This article uses the democratic peace theory to determine whether the major intervening variables - energy policy and transit potential in the Arctic - could inhibit the theoretically predicted behaviour of such states. Theoretical implication stemming from the literature review points to an inherently more peaceful nature of Russia in this space, unlike the rest of the world. This was an incentive to fill in an epistemological gap of the democratic peace puzzle. Following the logic of the democratic peace theory, this research has demonstrated that the two intervening variables have been omitted and thus they should be incorporated in further empirical research.
\end{abstract}

\section{Key words}

Arctic, energy policy, Russian Federation, democratic peace 


\section{Liberal peace promise for the Arctic: is the energy policy an omitted variable?}

The Arctic is a region which will serve as a territory on which major world powers will play the next "big game". Being characterized as a sui generis region, Arctic is dominated by Russian influence and immanent battle among world powers for the prestigious, unexplored (or at least underexplored) part of the globe. Besides anocratic Russia and the People's Republic of China (PRC), whose strategies and foreign policy actions towards the Arctic have been increasingly assertive with time, other major players such as the US, Canada, Norway, and the EU are also involved in the events in the region. With immense, unexplored crude energy resources, this region is becoming an object of growing interest to a myriad of state and private-owned multinational energy companies, whose presence influences international relations within this region. In academic discourse, the Arctic as a geographical realm presents a unique and expanding research issue (Daniels \& Mitchell, 2017; Marsh \& Kaufman, 2012; Øverland, 2010; Røseth, 2014; Wegge, 2011). This article is aimed at inspecting the official energy strategy and foreign policy of the Russian Federation towards the Arctic. The case of Russia has been selected as this state is the dominant and the most assertive actor within the region, whose decisions overwhelmingly shape the course of events in the Arctic. Among many potential theories within the international relations, the author deploys Democratic Peace Theory (DPT) as a middle-range scientific approach of liberal provenance, which was introduced back in the $1980 \mathrm{~s}^{1}$. Among the first ones who revived the Kantian idea of the perpetual global peace, Michael Doyle stood as the pioneer of the entitlement theory. It had evolved from intellectual liberal thought according to which the "internal variable" (political system/regime type) significantly influences a state's behaviour in the international arena. Such externalization of internal variable is also known in some realism-related approaches, but is not inherent there as it is in case of liberal theories. Ever since the DPT was introduced, its branching into several key approaches has begun. The very first theoretical split occurred at the beginning of the 1990s. As the initial DPT stance claimed that two democratic states were less likely to become involved in a conflict, the first

1 Even though some postulates of this theory originated quite earlier, in a modern sense, Michael Doyle (1983) was the one who set the basis of the modern DPT. 
significant division claimed that states with political regime of the democratic type are "inherently" more peaceful. This is what Rudolf J. Rummel introduced as the monadic version of democratic peace, a concept based on the said claim of inherently peaceful nature of democratic states (Rummel, 1995).

While explaining the reasons for a state's behaviour within the IR system, theorists usually cite definitions of democratic peace. The two main approaches to discussing the concept of democratic peace are (1) the institutional one, which explains democratic peace as the arrangement of political system constituents which shape foreign policy decisions, and (2) the normative explanations, which seek to include norms, values and democratic ideals that are translated beyond the national borders. Both vertical and horizontal differentiation of the DPT argumentation provided a very fruitful ground for a vast number of studies which statistically tested the initial hypotheses of the DPT (Rummel, 1995). As those tests made it possible to obtain a saturated model of war proneness, researchers moved their focus: the type and intensity of a conflict have been replaced in the role of dependent variables by such factors as military alliances, interventions, new types of conflicts and similar phenomena.

The Arctic has been considered for a long time to be an important scientific research object. The constantly growing number of academic papers in international relations suggests that a more concise and deeper analytical framework should be established for this topic. It is widely acknowledged in literature that this region deserves to be further empirically inspected (Øverland, 2010; Proroković, 2017; Wegge, 2011). This research intends to bring quite an innovative perspective, with an energy policy variable included in the analytical matrix of the DPT research. The author makes use of the prognostic capacity of the theory to determine whether the energy policy and transit potential of the Arctic inhibits conflict developments. Besides, it incorporates a new, potentially geographically pivotal space as a spatial unit of analysis.

This predominantly qualitative research is organized as follows. At first, the author will present an in depth review of the existing conceptions of the Arctic region. Besides the general definitions of the Arctic region, the author will imply that the energy potential of the region forms the main trigger for key global powers' involvement, with a particular emphasis on the Russian Federation. The central part of this article will be dedicated to describing Russia's energy strategy for the Arctic, its main objectives, goals and means of deeper involvement in the global battle for resources located there. As the author initially presumes that - in accordance with the logic of the DPT - the Arctic should be a conflictual area due to the huge differences in the political regime types of 
the involved states, the discussion will deal with the DPT's (lack of) success in this case, influenced by the involvement of the energy policy variable.

\section{Russia's aspirations towards the resource-rich Arctic}

The Arctic is a geographical area which lies in the high northern latitudes of the Earth. The 16,000 km-long Arctic circle surrounds the territory of 20 million sq $\mathrm{km}$, covering around $4 \%$ of the total Earth's surface (Marsh \& Kaufman, 2012). From a narrow, geographical point of view, the Arctic includes an area defined by the $10^{\circ} \mathrm{C}$ mean July isotherm; however, if viewed from the perspective of geostrategy (and therefore geopolitics) and the international and national security of the Arctic States, a significantly wider territory can be labelled as the "Arctic region" (Virtanen, 2013, p. 13). Despite the extreme living conditions resulting from low temperatures, and the fact that most of the Arctic's territory is covered by ice, some indigenous communities have managed to survive and establish settlements there. There are hardly any major cities within the polar circle. Most of settlements are populated by the citizens of Canada, Norway, Russia, and Sweden. However, sometimes the phrase "Arctic five" is used to refer to the states with territories within this region (Denmark/Greenland, Norway, Russia, the US and Canada). The Arctic's major and largest cities are Murmansk (with the population of 307,257$)$ and Norilsk $(175,365)$, both located in Russia, followed by the Norwegian city of Tromsø $(71,000)$. There are six indigenous communities in the Arctic in total: the Aleut International Association, the Arctic Athabaskan Council, the Gwich'in Council International, the Inuit Circumpolar Council, the Russian Association of Indigenous Peoples of the North, and the Saami Council ${ }^{2}$. They all enjoy the status of Permanent Participants on the Arctic Council and are deeply involved in everyday decision-making process in this part of the world.

Exploration of the Arctic opens a Pandora's box as the energy resources available there have been estimated to be abundant. In 2011 it was announced that the previous estimates of huge oil reserves had been more conservative than it was later discovered. The $\mathrm{BBC}$ claimed that crude oil \& gas reserves in the Arctic could be in the range of 160 billion barrels, compared to the initial estimate of 90 billion barrels (BBC, 2011). With China being an energy consuming nation,

2 For more on indigenous communities within the circumpolar area, see Rosamond, 2011. 
resources such as oil and gas are essential to the state's economic growth. The 2008 US Geological Survey estimated that the Arctic contained up to 30 per cent of the world's undiscovered gas reserves and 13 per cent of the world's undiscovered oil reserves (CSIS, 2019). Besides, this region contains huge deposits of gold, silver, diamonds, coal, copper, tungsten, zinc, manganese and chromium. The islands bordering the Arctic Circle are also thought to be rich in mineral resources. In such geographical configuration, Russia is naturally positioned as a central state within the high North (Roi, 2010). According to the claims included in its National Security Strategy for the period up to 2020, Russia considers the Arctic "as a strategic resource base" (Kremlin, 2009). Therefore, as the rules of geopolitics would imply, Russia takes a pivotal role compared to other states present in Arctic. Russia's historical aspirations towards the Arctic have been facilitated by the development of modern ice-breaking vessels. In addition to the Northern Sea Route and significant oil resources located there, it should be emphasized that the majority of the 37,000-kilometer-long Russia's coastline is the northern coast within the Arctic region; it is estimated that between 2 and 3.6 million inhabitants of Russia live in the area; $80 \%$ of Russian gas, $60 \%$ of copper, over $85 \%$ of nickel and cobalt and $95 \%$ of platinum group metals are produced in this zone, accounting for about $15 \%$ of gross domestic product and $20 \%$ of Russia’s total exports (Proroković, 2017, p. 271). In 2008, the then Russian President Dmitry Medvedev stated: "Our first and foremost task is to include the Arctic in Russia's resource base in the 21st century. The use of these resources will ensure the energy security of Russia as a whole" (Virtanen, 2013, p. 44).

Interests and policies within the Arctic region are formulated at the supranational level through the Arctic Council, an international forum comprising Canada, Denmark, Finland, Iceland, Norway, Russia, Sweden and the US. Among the countries with the observer status (including France, the UK and the Netherlands), the PRC stands out as it has been closely following the Council's work ever since it was granted such status in 2013. However, even though the Council was initially predicted to become a unique high-level intergovernmental forum which should provide a "means for promoting cooperation, coordination and interaction among the Arctic States, with the involvement of the Arctic Indigenous communities" (Arctic Council, 2019), this body seems to have failed to coherently manage the wide range of different states' policies in this region. For more than two decades of its existence, this forum has served as a consultative body without a significant role in interstate relations. 


\section{Russia's energy strategy for the Arctic}

Academic significance and research of Russian energy policy towards the Arctic is reflected in many papers which assess the discourses based on the two theoretical schools of thought within international relations - realism/geopolitics and liberalism (Pettersen, 2014; Proroković, 2017; Staun, 2017; Wegge, 2011). The realism discourse focuses on the "need for a security based, unilateralist approach to the Arctic" (Staun, 2017, p. 3), while the liberal one puts emphasis on accommodating to international law (Staun, 2017, p. 3), especially towards the UN legislation and its agencies' scope of activities. As Russia is a main superpower with global reach, its ambitious geopolitical shift towards the Arctic has been reflected in its strategic outlook. Besides numerous security strategies and lower level legislation (Arctic Strategy, National Security Strategy), Russia adopted two important documents which regulate its position towards the Arctic in the near future. In 2001, Russia formulated the "Foundations of the State Policy of the Russian Federation in the Arctic", while the first strategic-level act was adopted in 2008. Even though both of the documents define the way in which Russia should establish and promote itself in the region, none of these attach much significance to energy issues. They rather imply the need for geopolitical positioning within the scope of projected national interests of the Russian Federation. The cornerstone of the state policy of the Russian Federation in the Arctic for the period until 2020 and beyond is the document adopted by the Russian Government in 2010 (Ministry of Energy of the Russian Federation, 2010). The list of actors influencing Russia's strategy towards the Arctic is nonexhaustive as the said strategy is influenced by a variety of stakeholders, private businesses, and even other sovereign countries, out of which the most significant actor is the PRC, an emerging economic superpower.

Over the last seven years, Russia has increased bilateral strategic cooperation with the PRC regarding the Arctic. There are two dominant postulates in the literature which analyzes Russia-China relations with regard to Arctic-related issues. The first one presents an argument according to which Russia seeks to provide incentives towards deepening and bringing bilateral ties with the PRC in order to maintain Russian dominance in the Arctic, with China willingly consenting to Russian (predominantly military) activities in the high North. The second argument explains this partnership as necessary cooperation which should serve as a mutual response towards the potential Western presence in the region. 
Ever since the Chinese global Belt and Road Initiative (previously known as One Belt, One Road) was introduced in 2012, no single piece of land has remained beyond the scope of Chinese economic aspirations. Early academic endeavors followed the Chinese Arctic policy as a part of integral Belt and Road interests. Linda Jakobson and Jingchao Peng (2012) report that the return of a Chinese research vessel Xuelong from its fifth voyage to the Arctic was the event which paved the path towards further development of the Chinese Arctic policy. The authors believe that, despite being developed and funded by several ministries and agencies, China's polar policy is an important part of its foreign policy as some actions, such as the 2011 decision to build a new heavy icebreaker, were made directly by the State Council (Jakobson \& Peng, 2012, p. 4). Jakobson and Peng mention governmental institutions, commercial actors, universities and research centres as some of the key actors that influence foreign strategy for the Arctic (2012, p. 5). China's Arctic policy relies on growing transit potential resulting from the melting of the polar ice. It is clear that China does not aspire to establish its military presence over the Arctic, nor does it want to dominate the regional affairs. However, this state has a strong interest in having some preferential routes for shipping its goods towards Western markets. The PRC's Arctic policy is translated into the Northern Sea Route (NSR), which is an alternative to the Southern Sea Route. Tom Røseth (2014) calculates that travel time for the NSR is 35 days, comparing to 48 travel days for SSR (Røseth, 2014). However, while the NSR is shorter, it still has some disadvantages, such as the fact that it is a seasonal route due to extreme weather conditions. Røseth identifies weather and ice conditions, lack of proper infrastructure, as well as low search \& rescue capabilities as the main risks of using the NSR and he considers instability in the Middle East and piracy as the main risks specific to the Southern Sea Route (2014, p. 851). Even though in 2015 the percentage of transits using the NSR was at the verge of statistical significance, the Chinese Polar Research Institute forecast optimistic scenarios estimating that 5-15\% of China's international trade will go via the NSR by 2020 (Pettersen, 2014).

Russia's policy in the Arctic is not exclusively oriented towards the energy issues. It is an element of wider, integral global strategy actions addressed towards the challenges in the Arctic. Its cornerstone for this region is reflected within the strategic-level document Basics of the State Policy of the Russian Federation in the Arctic for the period until 2020 and for a further perspective (hereinafter "the Strategy"). This document was adopted in 2008, and after promulgation, came into force in 2009. The Strategy sets a basis on which Russia has been formulating its policy for 2009-2020 period. It lists four specificities of the Arctic 
zone of the Russian Federation that influence the formulation of the state's policy in the Arctic. Two of them relate to the extreme weather conditions and low sustainability of ecological systems connected with their high vulnerability to human impact. Russia also recognizes focal character of industrial-economic development of those territories and low population density in the region, while acknowledging remoteness from basic industrial centers, high resource consumption, and dependence on economic activities (Kremlin, 2009).

The most notable part of the strategy is dedicated to Russian national interests in the Arctic. Russia intends to use it as a "strategic resource base" providing a solution to the problems of social and economic development of the country, as well as to ensure that the Arctic remains a zone of peace and cooperation (Kremlin, 2009, p. 2). Maintaining peace and security is among the highest priorities of the strategy operationalized through the interests in the Arctic. The central part of Russia's strategic concept towards the Arctic stipulates the list of objectives and strategic priorities. In total, the strategy refers to seven objectives: setting up a regional system of search and rescue; increased activity of Russian governmental organs and nongovernmental organizations in international forums; mutually beneficial presence of Russia on the Svalbard-Spitsbergen archipelago; improving the quality of life of indigenous peoples; modernization of social infrastructure, including educational and health institutions; developing environmentally safe tourism; removing anthropogenic pollution from the Arctic; and research into the history, culture, and economics of the region (Kremlin, 2009).

Russia seems to have quite a complex and codified outlook on energy strategy, while its energy export policy is reflected through the Russian Government's decision-making dynamics. This is the key reason why the energy export policy in Russia's case could be seen as an instrument of soft power and hybrid warfare - it genuinely is an important asset of Russia's overall foreign policy. Being the global actor in energy production (and potentially consumption), Russia holds a vital role in European energy market supply. Besides the official Moscow standpoint, Russia's energy policy towards the Arctic is dependent on two groups of stakeholders. The first group consists of Russian state-owned companies dealing with fuel resource extraction as well as energy production and supply, such as Gazprom, Lukoil, OHS Consortium, Atomenergoprom, Rosatom and other major companies; among them Gazprom Neft is the largest Russian transnational company and thus the most important one. Its business is primarily oriented towards oil and natural gas expansion, production, refining, and transport to the end-users. With approximately 5.1 billion euros of net profit in 2018, this company operates in 15 countries worldwide (Gazpromneft, 2019). Though some view Russia's gas 
export as taking a "pivot to Asia", it is usually argued that Europe will remain of vital importance as a major market for Russian gas for the foreseeable future (Sakai, 2017). Following the initial decision to formulate its national energy policy in 1992, Russia adopted its first codified Energy Strategy in 1994. This strategy enacted the restructuring of fuel and energy industry of Russia for the period up to 2010 . This fifteen-year strategy encompassed certain very basic elements such as importance of political cooperation, need to improve technologies, and diversification of the export markets. However, internal political issues within Russia were a major obstacle in achieving even those very general goals. The modern strategic framework of the Russian Federation's energy policy is reflected in the energy Strategy adopted in 2010. The Strategy enacts several key priorities such as increase in energy efficiency, reducing the impact on the environment, sustainable development, energy development and technological development, as well as improved effectiveness and competitiveness (Ministry of Energy of the Russian Federation, 2010). It also points to Russia's endeavours in maximizing the effective use of natural energy resources and the potential of the energy sector "to sustain economic growth, improve the quality of life of the population and promote strengthening of foreign economic positions of the country" (2010, p. 6). Russia's strategic outlook is highly dependent on two large groups of external and internal challenges; in each case, two main trends could be identified: the ones that Moscow officially recognizes within its strategic and legislative acts, and the ones it does not consider important enough to pre-emptively include them in the official documents (Dimitrakopoulou \& Liaropoulos, 2010). Russia's position was initially described as "one of the world's major powers", while nine years later this statement was softened by a claim that "transformation of the Russian Federation into one of the leading powers could make an influence to ongoing world processes" (2010, p. 6).

All of these strategic goals were translated into concrete projects out of which two major ones are the most important - the Barents Sea Shtokman project and the Bovanenko project on the Yamal Peninsula. Developing the Yamal fields fully would cost several hundred billion dollars and could take up to 50 years. On the other hand, Yamal is relatively conveniently located considering Russia's existing pipelines from Nadym Pur Taz to domestic and foreign markets (Øverland, 2010, p. 873). The accelerated ice melting now evident in the Arctic Ocean also opens opportunities for marine transportation of liquid natural gas from the Yamal Peninsula and the offshore fields. The Shtokman gas and condensate field was discovered in 1988 and is estimated to contain 3.8 trillion cubic metres of gas and 31 million tons of condensate (Øverland, 2010, p. 873). Øverland reports 
that the Shtokman field alone contains "enough gas to satisfy the entire consumption of the EU for seven years" (2010, p. 875). This illustrates the importance of Russia's Arctic energy projects for international energy markets. The Shtokman exemplifies how Arctic energy projects can link countries within and beyond the Arctic in constructive cooperation - quite contrary to the image of a geopolitical race over energy resources driven by Russian aggression (2010, p. 875).

\section{Has the democratic peace concept failed in the Arctic case?}

To be able to produce any DPT analysis which would serve its classic empirical purpose, a set of preconditions needs to be provided. The major obstacle for this research lies in the fact that not many statistically useful cases are available, as only a few actors (sovereign states) are involved in the Arctic region. This is why the classical democratic peace analysis could not be done on the basis of Large-N data. Instead a qualitative research design was adopted in this study. The section below discusses to what extent the DPT has failed in the Arctic's case, and whether energy policy was a key variable which changed the situation in the area.

In his article published in 2011, Njord Wegge introduces three potential theoretical perspectives which, according to his stance, are the most useful in explaining events within the polar circle. The first one is Charles Kindleberger's theory of hegemonic (or unipolar) stability. Wegge argues that the Arctic states focus on military presence, protection of sovereign rights, and the vast economic resources makes this theory "highly relevant theoretical perspective in an analysis of the political order in the region" (Wegge, 2011, p. 168). The second potentially useful theoretical framework is the theory of stability under a multipolar balance of power. Wegge argues that the balance of power theory is successful in explaining how some power capabilities could be operationalized and measured in a way to provide a valid scientific output. Among many potential capabilityrelated factors, Wegge distinguishes five dominant ones: military capabilities, economic strengths, administrative capacity, control over natural resources, and control over territories (2011, p. 169). Eventually, he believes that the third important epistemological basis for understanding the situation in the Arctic could be the theories of the international Kantian society. Wegge finds that three postulates stemming from Kant's internationalism ${ }^{3}$ "each emphasise features found in international politics in today's Arctic” (2011, p. 168).

3 Wegge lists an "empirically scrutinized" assumption that democracies do not wage war with each other; the English school focuses on the anarchical society constituted 
The democratic peace theory would initially presume that the Arctic would be anything but the peaceful and stable zone. The fact that the key states involved have heterogeneous types of political regimes (with the Western democracies, and autocratic Russia and China) is a sufficient precondition for development of potential armed conflicts (Dafoe et al., 2013; Gartzke \& Hewitt, 2010; Sweeney, 2003). According to the data extracted from the Polity IV dataset, the Russian Federation is a state with mostly anocratic political regime ${ }^{4}$. With the Polity IV score of 4 (on a scale between -10 and +10 ), Russia's progress towards further democratization seems to have stalled. Over the last decade, during the same period the PRC received -7 on the same Polity IV score, which describes this country's regime as autocratic. On the other hand, the states of the "global West" are all democratic, with some of them being consolidated democracies (Canada, Norway). Having in mind these differentiations, the DPT serves as a potentially solid basis on which the predictions regarding events in the Arctic could be made.

However, energy policy and the transit potential over the Arctic are the two central variables that significantly change the democratic peace postulates, at least in the Arctic region. During the regular meeting of the Arctic Council in the Norwegian city of Tromsø in 2009, Russia's foreign minister Sergei Lavrov stated that Russia was not planning to increase its military presence in the Arctic or to deploy armed forces there (Ria Novosti, 2009). Several years later, Russia was maintaining a military base there, and a brigade under the Northern Fleet Joint Strategic Command (Sakai, 2017). Annika Rosamond agrees that even though Russia seeks to expand the area of its sovereignty (i.e. claiming the rights to the Lomonosov Ridge), it would be "unlikely that it would instigate a conflict in the Arctic, since this would impede upon its future trade and commercial interests by making the circumpolar north an unstable region" (Rosamond, 2011, p. 42). Generally, it could be concluded that the Arctic region can be characterized as peaceful rather than unstable. Russia's national security interests and goals primarily have depended on the ongoing crises and conflicts. Back to the war it led in Georgia in 2008, and its heavy involvement in Ukraine of 2014, and then

by states which share certain rules, customs, values, and norms, while regime studies, in which international law and organizations are treated as autonomous or partly independently intervening causal variables in political development, as three dominant theoretical discourses stemming from the Kantian internationalism (Wegge, 2011).

${ }^{4}$ For comprehensive explanation of anocracy and anocratic political regime in political science, see Gurr, 1974. 
in the Syrian conflict, Russia seemed to be a "free-rider" in developing and conceptualizing its national security strategic acts. It proceeded to re-examine and adapt its security and defence documents after the Ukrainian crisis, in line with a more assertive strategy towards its European neighbours. Whereas the stated goals emphasize multilateralism, balance of powers and unrestricted cooperation, they do not capture the full range of activities envisaged by the Kremlin to enhance Russian security. The overarching goal behind the commitments stated in strategy documents is to make Russia a competitor of equal rank to other great powers on the global scene, i.e. an actor able to resort to the full use of resources that are the components of the state power in the 21st century. Jørgen Staun argues that Russia's decision-making process concerning Arctic affairs is "to a large extent exempted from the general centralization of decision making which seems to have hit other policy areas, such as for example accounts on the decision to invade Ukraine" (Staun, 2017, p. 3). It is for these reasons that Russia's policy towards the Arctic is sui generis an integral part of its foreign policy.

\section{Will Russia's energy strategy towards the Arctic remain unchanged?}

This article is an attempt to demonstrate that democratic peace postulates do not necessarily need to reflect the classic DPT theoretical setting. On the contrary, the political regime similarity as a precondition for peace had clearly been invalid in the case of the Arctic, as no major disputes have been registered in that area in the last 50 years. The author has argued that energy policy and transit potential of the Arctic are intervening variables that could potentially skew theoretical predictions in accordance to which the Arctic should be(come) a conflict-prone area. This article has also brought into the research agenda a significant impetus and additional knowledge to fill the theoretical gap related to this unusual international relations setting for democratic peace. Indirectly, this research sought to provide a possible response to the most pressuring issue: why are there no open conflicts in the Arctic region? This analysis started with searching for adequate answers to several issues: What is the scientific approach most adequate in analyzing the Arctic politics of major powers? What are the largest discrepancies among the stakeholders and actors involved? How can some sector policies such as energy policy gain influence and change the rules of the game? How will these developments be carried out by the Russian Federation as the dominant party in Arctic-related matters events? 
The future of Russia's energy policy in the Arctic is not so difficult to predict as it was initially feared by academics. Some authors speculate that when observed in the context of the Arctic, Russia's policy does not look like a revisionist power (Staun, 2017, p. 3). Rather than that, Staun claims that it looks more like a status quo power "following a well established long term strategy" (2017, p. 3).

Russia is being challenged by other superpowers and international organizations. For instance, NATO has acknowledged reintroduction of military concerns reflected in the "gradual" aspect which is based on the steady reintroduction of army, navy and air force elements into the region by major Arctic players (NATO, 2019). This is also an important impetus towards the potential change of Russia's Arctic energy strategy. As the three key theoretical approaches (power capabilities, international regimes, and domestic regime type of Arctic states) were identified as the most fruitful ones, the findings of this research imply the need for further research endeavours. It is highly likely that Russia's behaviour in the Arctic during the next decade will be impacted by its aspirations to being a great power, its relationship with other great powers, and all kinds of resources it has at its disposal as a support for its Arctic ambitions.

\section{REFERENCES}

Aalto, P., \& Jaakkola, I. (2015). Arctic energy policy: global, international, transnational and regional levels. In J. C. Jensen \& G. Hønneland (eds.), Handbook of the Politics of the Arctic. Cheltenham: Edward Elgar Publishing.

BBC (2011). Arctic oil exploration: Potential riches and problems. Retrieved from https:// www.bbc.com/news/business-14728856

CSIS (2019). Is Russia Winning the Race to Develop Arctic Energy. Retrieved from https://www.csis.org/analysis/russia-winning-race-develop-arctic-energy

Dafoe, A., Oneal, J. R., \& Russett, B. (2013). The democratic peace: Weighing the evidence and cautious inference. International Studies Quarterly, 57(1), 201-214.

Daniels, K., \& Mitchell, S. M. (2017). Bones of democratic contention: Maritime disputes. International Area Studies Review, 20(4), 293-310.

Dimitrakopoulou, S., \& Liaropoulos, A. (2010). Russia's National Security Strategy to 2020: A Great Power in the Making? Caucasian Review of International Affairs, 4(1), $35-51$.

Gartzke, E., \& Hewitt, J. J. (2010). International crises and the capitalist peace. International Interactions, 36(2), 115-145.

Gazpromneft (2019). Gazpromneft at a Glance. Retrieved from https://www.gazpromneft.com/company/at-a-glance

Gurr, T. R. (1974). Persistence and change in political systems, 1800-1971. American Political Science Review, 68(4), 1482-1504. 
Kremlin (2009). Basics of the State Policy of the Russian Federation in the Arctic for the period until 2020 and for a further perspective. Moscow: Rossiyskaya Gazeta.

Lasserre, F., Huang, L., \& Alexeeva, O. V. (2017). China's strategy in the Arctic: threatening or opportunistic? Polar Record, 53(1), 31-42.

Jakobson, L., \& Peng, J. (2012, Nov). China's Arctic Aspirations. SIPRI Policy Paper, 34, 36. Marsh, W. M., \& Kaufman, M. M. (2012). Physical Geography: Great Systems and Global Environments. Cambridge: Cambridge University Press.

Ministry of Energy of the Russian Federation (2010). Energy Strategy of Russia for the period up to 2030. Moscow: Russian Federation.

Øverland, I. (2010). Russia’s Arctic energy policy. International Journal, 65(4), 865-878.

Proroković, D. (2017). Regionalna bezbednost i teorija realizma: studija slučaja Arktik. (Doctoral dissertation, Univerzitet u Beogradu-Fakultet bezbednosti).

Ria Novosti. (2009). Russia against increasing military presence in Arctic - Lavrov. Retrieved from http://en.rian.ru/world/20090429/121374139.html

Roi, M. L. (2010). Russia: The Greatest Arctic Power? The Journal of Slavic Military Studies, 23(4), 551-573.

Rosamond, A. (2011). Perspectives on Security in Arctic Area. Kopenhagen: Danish Institute for International Studies.

Røseth, T. (2014). Russia's China Policy in the Arctic. Strategic Analysis, 38(6), 841-859.

Rummel, R. J. (1995). Democracy, Power, Genocide, and Mass Murder. Journal of Conflict Resolution, 39(1), 3-26.

Sakai, S. (2017). Russia and Energy Transactions in Northeast Asia. In J. Huang \& A. Korolev (eds.), The Political Economy of Pacific Russia (pp. 129-155). Palgrave Macmillan. DOI: 10-1007/978-3-319-40120-1

Security Council of the Russian Federation (2000). Russia's National Security Concept 2000, Retrieved from https://www.bits.de/EURA/natsecconc.pdf

Staun, J. (2017). Russia's Strategy in the Arctic: Cooperation, Not Confrontation. Polar Record, 53(3), 314-332.

Sweeney, K. J. (2003). The Severity of Interstate Disputes: Are Dyadic Capability Preponderances Really More Pacific? Journal of Conflict Resolution, 47(6), 728-750.

Pettersen, T. (2013). China Starts Commercial Use of Northern Sea Route. BarentsObserver. Retrieved from http://barentsobserver.com/en/arctic/2013/03/china-startscommercial-usenorthern-sea-route-14-03

USGS. (2008). Circum-Arctic Resource Appraisal: Estimates of Undiscovered Oil and Gas North of the Arctic Circle. USGS Fact Sheet. Denver: U.S. Geological Survey.

Virtanen, V. (2013). The Arctic in World Politics. The United States, Russia, and China in the Arctic-Implications for Finland. Harvard University: Weatherhead Center for International Affairs.

Wegge, N. (2011). The Political Order in the Arctic: Power Structures, Regimes and Influence. Polar Record, 47(2), 165-176. 